\title{
BENTHIC MACROINVERTEBRATES AS BIOINDICATORS OF WATER QUALITY IN THE BLYDE RIVER OF THE OLIFANTS RIVER SYSTEM, SOUTH AFRICA
}

\author{
MalAKANE, K. - AdDo-BediaKo, A. ${ }^{*}$ - KeKANA, M. \\ Department of Biodiversity, University of Limpopo \\ Private Bag X1106, Sovenga 0727, South Africa \\ *Corresponding author \\ e-mail: abe.addo-bediako@ul.ac.za; ORCID:0000-0002-5055-8315 \\ (Received $4^{\text {th }}$ Oct 2019; accepted $8^{\text {th }}$ Jan 2020)
}

\begin{abstract}
The Olifants River System and its catchment have been exposed to prolonged and cumulative ecosystem stress as a result of human settlements, mining, agricultural and industrial activities. The Blyde River is known to supply the Olifants River with water of good quality and quantity. However, theintensive farming and human settlements in the catchment could threaten the river. The aim of the study was to assess the water quality of the Blyde River in South Africa using aquatic macroinvertebrates as bioindicators. Seven sites along the river were selected for sampling. The family composition, based on abundance and diversity was evaluated in relation to environmental variables. The results of some measured physicochemical parameters revealed that water quality of the Blyde River is not significantly altered and the presence of ecologically sensitive macroinvertebrates was an indication of good water quality as this benthic fauna was well represented in all seasons and most parts of the river. The study therefore has indicated that the river was inhabited by a healthy macroinvertebrate community suggesting that the water is still of good quality.
\end{abstract}

Keywords: anthropogenic activities, bioassessment, environmental factors, spatial distribution, water pollution

\section{Introduction}

Many river systems have been subjected to a range of disturbances due to the fastgrowing human population and increasing human activities, and leading to water quality degradation (Jun et al., 2016; Ferreira et al., 2017; Santos et al., 2017; Niba and Sakwe, 2018). The effluents from activities such as, industries, mining, agriculture, domestic and urban development contain various pollutants, which often end up in water bodies and may affect the ecological status of the river (Dalu and Froneman, 2016; Hunt et al., 2017).

Benthic macroinvertebrates respond differentially to biotic and abiotic factors in their environment and therefore, the structure of macroinvertebrates has long been used as bio-indicators to assess the water quality of water bodies (Li et al., 2010; Wolmarans et al., 2014; Jun et al., 2016). Benthic macroinvertebrates are the most common faunal assemblages for bio-assessment and provide more reliable assessment of long-term ecological changes in the quality of aquatic systems compared to its rapidly changing physicochemical characteristics. Their multiple life stages, sedentary nature, and varying tolerance levels to environmental stressors render them useful in assessing temporal and spatial changes within an aquatic ecosystem (Rosenberg and Resh, 1993). However, specific preferences for certain ranges of abiotic and biotic characteristics, mean that changes in these factors often create large differences in benthic community structure even over small spatial scales (Grönroos and Heino, 2012). Different groups of 
macroinvertebrates have different environmental requirements and respond to changes in environmental factors, such as temperature, dissolved oxygen, conductivity and salinity (Külköylüoğlu, 2004; Grab, 2014; Masese et al., 2014). Thus, the degree of tolerance of these factors vary among different organisms, and information gathered from such studies reflect the quality of water in the river.

The Olifants River System provides water for industrial, mining, agricultural and domestic uses (Machete et al., 2004). Along the Olifants River, pollution arising from intensive and subsistence agriculture practices in all the sub-catchment and the numerous point- and non-point-sources (diffuse), including mining and industrial pollution in the Upper Olifants catchment area contain complex mixtures of chemicals, many of which may have deleterious effects on aquatic systems. Due to these various activities in its catchment, the river has become one of the most polluted rivers in South Africa (Grobler et al., 1994; Addo-Bediako et al., 2018). Many of the impoundments and tributaries of the Olifants River System are said to be contaminated with heavy metals, inorganic nutrients such as, sulphates and nitrates from agricultural areas, mine drainages and wastewater treatment (WWT) plant (Oberholster et al., 2013). The Blyde River is an important tributary of the Olifants River (Ashton et al., 2001). It is known for its continuous flow and good water quality (Raven, 2004). However, the recent human activities in the catchment may be impacting the quality of the water and the biota e.g. macroinvertebrates. Thus, the study assessed the water quality of the Blyde River using aquatic macroinvertebrate communities. The objectives of this study were: (i) to describe the spatial distribution and assemblage structures of macroinvertebrates; (ii) to determine major environmental variables that affect their distribution. We hypothesize that: environmental conditions play important role in the distribution and abundance of aquatic macroinvertebrates.

\section{Materials and methods}

\section{Study area}

The Blyde River rises on the western slopes of the Drakensberg Mountains (Mpumalanga) and flows northwards to join the Olifants River in Limpopo Province, South Africa (Raven, 2004). The catchment is approximately $2000 \mathrm{~km}^{2}$ in size. The mean annual precipitation is about $1000 \mathrm{~mm}$ and it is considerably higher than the other sub-catchment areas in the Olifants River Basin (Raven, 2004). Seven sampling sites were selected along the river (Fig. 1). S1 (24³0'59.46”S 30 47'56.14'E), S2 (2430'14.42”S $\left.\quad 30^{\circ} 50^{\prime} 08.49^{\prime \prime} \mathrm{E}\right) . \quad$ S3 $\quad\left(24^{\circ} 25^{\prime} 52.45^{\prime \prime} \mathrm{S} \quad 30^{\circ} 50^{\prime} 03.59^{\prime \prime} \mathrm{E}\right), \quad$ S4

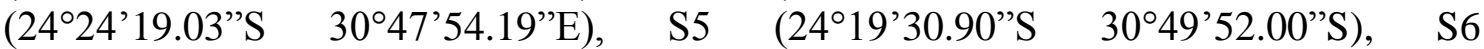
(2423'04.94"S 3048'22.09'E) and S7 (24¹5'30.38'S 3050'13.22'E). The sites represent four different groups of land use; domestic (S1 \& S2), agriculture (S3 \& S5), industrial (S4) and nature reserves (S6 \& S7).

\section{Physicochemical parameters}

This study was conducted in winter (July) and spring (October) of 2017, summer (January) and autumn (April) of 2018. Seasonal water samples were collected in $1000 \mathrm{ml}$ polyethylene bottles (acid pre-treated) and stored at $4{ }^{\circ} \mathrm{C}$ prior to analysis. Seasonal environmental variables, such as $\mathrm{pH}$, water temperature, dissolved oxygen, (DO), total dissolved solids (TDS) and electrical conductivity were recorded at the 
sampling sites using a YSI Model 554 Data logger, for the characterization of each sample point. Water current (flow velocity) was measured using a portable flowmeter Model 2000 (Marsh McBirney, Maryland, US). Channel width and water depth were measured using a tape measure and graduated measuring rod, respectively. Laboratory analysis was conducted to determine the nutrients $\left(\mathrm{NH}_{4}, \mathrm{NO}_{2}, \mathrm{NO}_{3}\right.$ and $\left.\mathrm{PO}_{4}\right)$, turbidity, sulphates using a spectrophotometer (Merck Pharo 100 Spectroquant $^{\mathrm{TM}}$ ) with Merck cell test kits in the Biodiversity Water Laboratory, University of Limpopo.

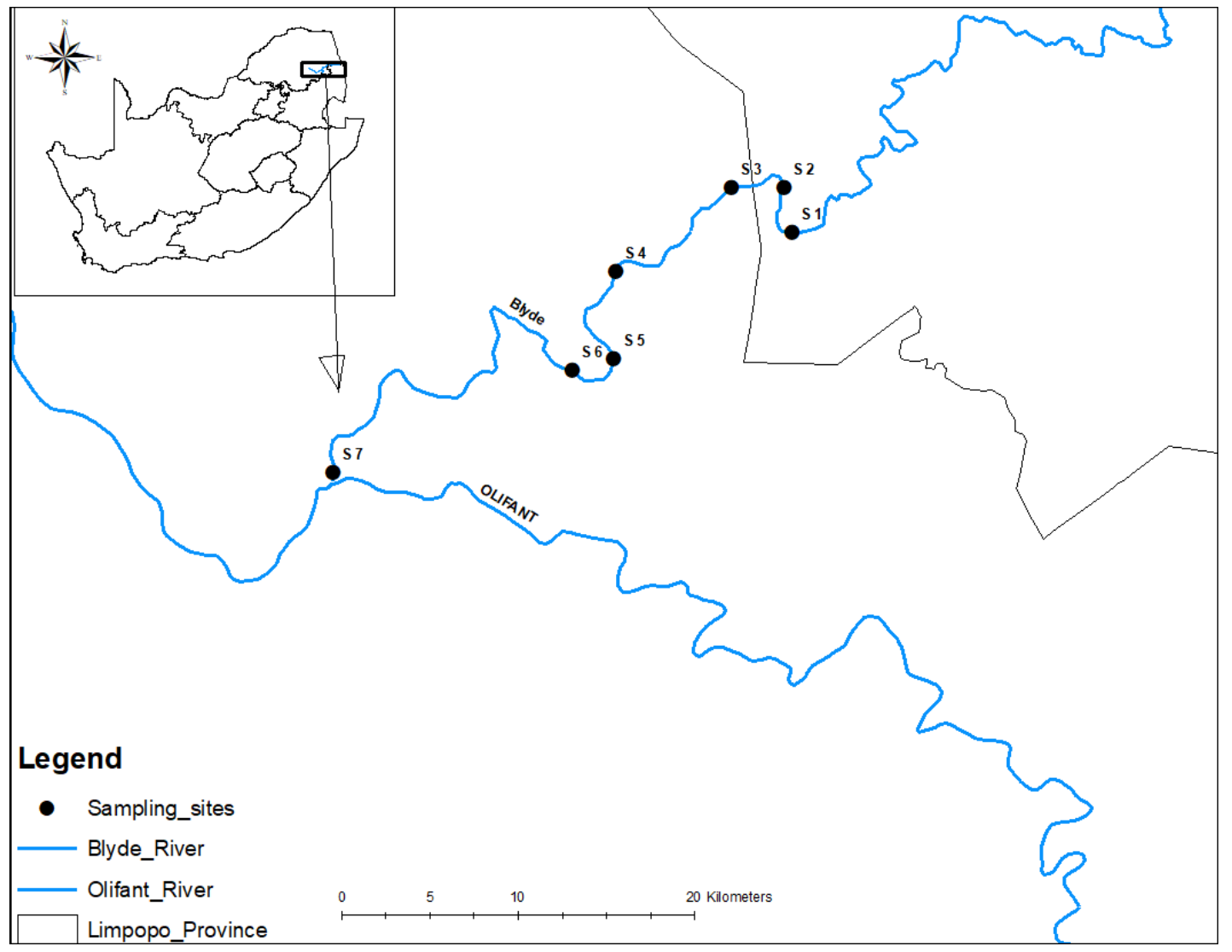

Figure 1. Map of the study area, showing the locations of the seven sampling sites of the Blyde River

\section{Sampling of macroinvertebrates}

Seasonal benthic macroinvertebrate samples were collected at seven sites (S1, S2, $\mathrm{S} 3, \mathrm{~S} 4, \mathrm{~S} 5$, S6 and S7) of the river. The samples were collected within a 100-m stretch of the study sites, with substrata of biotypes consisting mainly of mud, sand, gravel or stones. Samples were collected using a $30 \mathrm{~cm}$ by $30 \mathrm{~cm}$ sampling net with a $500 \mu \mathrm{m}$ mesh size. Benthic macroinvertebrates were collected using the kick sampling method described by Dickens and Graham (2002), whereby the substrate was disturbed by kicking for a period of $5 \mathrm{~min}$ to free macroinvertebrates. The samples were collected per site from all aquatic habitats (i.e. riffles, pools and vegetated margins). For the vegetation biotopes, macroinvertebrates were sampled by scraping the net back and forth through vegetation (approximately $2 \mathrm{~m}$ ). The macroinvertebrates were then separated from organic and mineral matter, counted, after identification to the family 
level using Gerber and Gabriel's field guide manual (2002)), and released back into the river. Where specimens could not be identified in the field, the samples were preserved in $70 \%$ ethanol and transported to the University of Limpopo's Biodiversity laboratory for further identification, with an aid of a stereomicroscope (Leica EZ4) and a magnifying glass. The South African Scoring System (SASS 5) were further used to classify the macroinvertebrates collected into three groups, namely tolerant (scores 15), moderately tolerant (scores 6-10) and sensitive (scores 11-15) to pollution (Dickens and Graham, 2002).

\section{Statistical analysis}

The mean and standard deviation of the respective water variables were calculated. Data were first tested for normality and homogeneity of variance using the Kolmogorov- Smirnoff and Levene's tests respectively. The analysis of variance (ANOVA) was performed to determine whether there were significant differences among the different sites and seasons (winter, spring, summer and autumn) in water variables. Canonical correspondence analysis (CCA) was used to relate macroinvertebrate assemblages to environmental variables and to identify which environmental variables could best differentiate them (Jun et al., 2016). Monte Carlo simulations were carried out to verify whether the variables exerted a significant effect $(p<0.05)$ on macroinvertebrate distributions. Taxa abundance data were transformed to $\log (x+1)$ in both analyses to down-weight the effects of dominant taxa. Square-roottransformation was used for the environmental parameters and were transformed to log $(\mathrm{x}+1)$ except $\mathrm{pH}$. CCA were conducted using CANOCO version 5.1 software (ter Braak and Šmilauer, 2002). Spearman correlation coefficients between macroinvertebrates and environmental variables were calculated to assist interpretation of changes in community profile using STATISTICA software (StatSoft, Inc., version 10, Tulsa, OK, USA).

\section{Results}

\section{Physicochemical parameters}

The physicochemical parameters of the water are summarised in Table 1. The lowest mean temperature $\left(22.3^{\circ} \mathrm{C}\right)$ was recorded at Site 1 and the highest mean temperature at $\mathrm{S} 7\left(24.90^{\circ} \mathrm{C}\right)$. The highest mean dissolved oxygen (DO) was recorded at S2 $(11.85 \mathrm{mg} / \mathrm{l})$ and the lowest was recorded at $\mathrm{S} 5(8.70 \mathrm{mg} / \mathrm{l})$. The $\mathrm{pH}$ was slightly alkaline at all sites and showed little variation. The $\mathrm{pH}$ ranged from 8.3 at $\mathrm{S} 5$ to 8.7 at $\mathrm{S} 1$. The lowest mean EC $(270.85 \mathrm{mS} / \mathrm{m})$ was recorded at $\mathrm{S} 1$ and the highest $(442.20 \mathrm{mS} / \mathrm{m})$ was recorded at $\mathrm{S} 5$, while the lowest mean TDS $(132.9 \mathrm{mg} / \mathrm{l})$ was recorded at $\mathrm{S} 1$ and the highest $(252.80 \mathrm{mg} / \mathrm{l})$ was recorded at $\mathrm{S} 7$. The mean salinity ranged from $0.25 \%$ at $\mathrm{S} 1$ to $0.49 \%$ at $\mathrm{S} 7$. There was a very strong positive correlation between $\mathrm{pH}$ and DO $(\mathrm{r}=0.92, \mathrm{p}<0.05)$. There were no significant differences in the above physicochemical parameters among the sites and seasons $(\mathrm{p}>0.05)$, except seasonal variation in temperature and salinity $(\mathrm{p}<0.05)$. However, S3 and S5 had the highest TDS and EC values but low DO values. Whilst S1, S2 and S6 exhibited low TDS and EC values but high DO values. Turbidity levels were within the recommended values. The nutrients levels were generally low except ortho-phosphate. 
Table 1. Average values of physicochemical variables measured at different sites along the Blyde River

\begin{tabular}{|c|c|c|c|c|c|c|c|c|c|c|c|c|c|c|c|c|c|}
\hline \multirow{2}{*}{$\begin{array}{c}\text { Water quality } \\
\text { parameters }\end{array}$} & \multicolumn{2}{|c|}{ S1 } & \multicolumn{2}{|c|}{$\mathbf{S 2}$} & \multicolumn{2}{|c|}{ S3 } & \multicolumn{2}{|c|}{ S4 } & \multicolumn{2}{|c|}{ S5 } & \multicolumn{2}{|c|}{ S6 } & \multicolumn{2}{|c|}{ S7 } & \multirow[b]{2}{*}{$\mathbf{F}$} & \multirow[b]{2}{*}{ p-value } & \multirow{2}{*}{$\begin{array}{l}\text { Water quality } \\
\text { guidelines }\end{array}$} \\
\hline & AVE & \pm SD & AVE & \pm SD & AVE & \pm SD & AVE & \pm SD & AVE & \pm SD & AVE & \pm SD & AVE & \pm SD & & & \\
\hline $\mathrm{pH}$ & $8.4-9.0$ & - & $8.4-8.9$ & - & $8.3-8.7$ & - & $8.2-8.8$ & - & $8.1-8.5$ & - & $8.2-8.8$ & - & $8.2-8.8$ & - & 0.63 & 0.372 & $6.5-9.0^{2}$ \\
\hline Temp $\left({ }^{\circ} \mathrm{C}\right)$ & 22.33 & 2.01 & 22.28 & 2.30 & 23.53 & 1.71 & 22.88 & 2.54 & 23.65 & 2.58 & 23.95 & 3.49 & 24.90 & 3.49 & 4.87 & 0.042 & \\
\hline $\mathrm{EC}(\mathrm{mS} / \mathrm{m})$ & 270.85 & 346.6 & 274.9 & 361.8 & 341.4 & 260.6 & 338.9 & 449.8 & 442.2 & 547.0 & 366.7 & 357.8 & 333.7 & 357.8 & 0.83 & 0.321 & - \\
\hline TDS (mg/l) & 132.9 & 32.2 & 138.5 & 35.4 & 147.2 & 43.7 & 250.9 & 158.0 & 241.2 & 79.4 & 158.6 & 76.64 & 252.8 & 76.64 & 0.46 & 0.315 & \\
\hline DO (mg/l) & 11.045 & 1.35 & 11.85 & 2.45 & 9.93 & 2.45 & 10.7 & 1.33 & 8.70 & 1.85 & 9.38 & 1.31 & 10.63 & 0.15 & 0.742 & 0.156 & - \\
\hline Salinity (\%o) & 0.25 & 0.34 & 0.27 & 0.37 & 0.35 & 0.47 & 0.38 & 0.51 & 0.46 & 0.59 & 0.38 & 0.51 & 0.49 & 0.63 & 18.29 & $<0.001$ & $<0.5 \%{ }^{1}$ \\
\hline $\mathrm{NO}_{2}(\mathrm{mg} / \mathrm{l})$ & 0.02 & 0.01 & 0.01 & 0.00 & 0.01 & 0.00 & 0.00 & 0.00 & 0.01 & 0.01 & 0.00 & 0.00 & 0.005 & 0.00 & 0.76 & 0.216 & $0.06^{3}$ \\
\hline $\mathrm{NO}_{3}(\mathrm{mg} / \mathrm{l})$ & 0.65 & 0.50 & 0.55 & 0.10 & 0.00 & 0.00 & 0.15 & 0.00 & 0.25 & 0.00 & 0.33 & 0.05 & 0.375 & 0.05 & 1.32 & 0.112 & $10.0^{3}$ \\
\hline $\mathrm{NH}_{3}(\mathrm{mg} / \mathrm{l})$ & 0.06 & 0.00 & 0.05 & 0.00 & 0.04 & 0.00 & 0.05 & 0.00 & 0.03 & 0.00 & 0.03 & 0.03 & 0.065 & 0.03 & 1.89 & 0.065 & $<0.007^{1}$ \\
\hline Ortho- $\mathrm{PO}_{4}(\mathrm{mg} / \mathrm{l})$ & 0.22 & 0.0 & 0.16 & 0.32 & 0.40 & 0.00 & 0.25 & 0.00 & 0.03 & 0.00 & 0.18 & 0.20 & 0.13 & 0.20 & 5.24 & 0.421 & - \\
\hline $\mathrm{SO}_{4}(\mathrm{mg} / \mathrm{l})$ & 17.35 & 5.27 & 16.90 & 4.75 & 18.03 & 4.92 & 17.05 & 4.14 & 24.00 & 3.92 & 14.93 & 6.27 & 25.95 & 6.27 & 4.41 & 0.037 & - \\
\hline Turbidity NTU & 14.00 & 8.69 & 14.00 & 12.88 & 6.75 & 2.05 & 7.50 & 2.69 & 13.25 & 10.99 & 7.75 & 5.24 & 10.25 & 3.34 & 1.69 & 0.072 & $8-<50^{2}$ \\
\hline
\end{tabular}

${ }^{1}$ DWAF (1996)

${ }^{2}$ BC-MECCS (2019)

${ }^{3} \mathrm{CCME}(2012)$ 


\section{Macroinvertebrates}

A total of 19832 individuals belonging to 11 orders and 36 families were collected at the various sampling sites and seasons. The total number of specimens collected per site for the seasons ranged from 1053 at S3 to 6876 at S5 (Table 2a). The highest number of families (32) was found at S6 and the lowest (23) was found at S7. The dominant taxa were Hydropsychidae (3 683), followed by Caenidae (2 519), Baetidae (2 483), Simuliidae (2 218), Chironomidae (1 499), Elmidae (1 160) and Corbiculidae (1 079). S1 was dominated by generalist Caenidae, sensitive Hydropsychidae and Baetidae, S2 by generalist Caenidae, sensitive Baetidae and Hydropsychidae, S3 by sensitive Hydropsychidae, Baetidae and Heptageniidae, S4 by sensitive Baetidae, Hydropsychida and Hydropsychidae, S5 by sensitive Hydropsychidae and tolerant Chironomidae and Simuliidae, S6 by tolerant Simuliidae, sensitive Hydropsychidae and generalist Caenidae, and S7 by tolerant Thiaridae, sensitive Hydropsychidae and sensitive Baetidae. The highest macroinvertebrate diversity (32 families) was recorded at S6 and the lowest (23 families) was recorded at S7. S7 had low diversity but high numbers of certain taxa e.g. Thiaridae. Taxa richness ranged between 24 during summer and 33 in spring (Table $2 b$ ). Taxa richness differed among seasons $(\mathrm{p}<0.05)$. The lowest number of individual macroinvertebrates were recorded during summer and the highest during winter, about ten times higher than that of summer.

Cluster analysis produced three main clusters of sites based on macroinvertebrate taxa (Fig. 2a). The first cluster was S5, the second was S6, and the third was a cluster of S1, S2, S3, S4 and S7. Spearman correlation was used to show the relationships among the sites (Table 3). The correlation yielded positive correlations among all the sites with respect to the macroinvertebrate families. The strongest correlations were between $\mathrm{S} 1$ and $\mathrm{S} 2(\mathrm{r}=0.813), \mathrm{S} 3$ and $\mathrm{S} 4(\mathrm{r}=0.812)$, and the weakest correlation was between $\mathrm{S} 1$ and S5 $(\mathrm{r}=0.431)$. Furthermore, even the seasonal variation across the sites rarely indicated any variation (Fig. 2b).

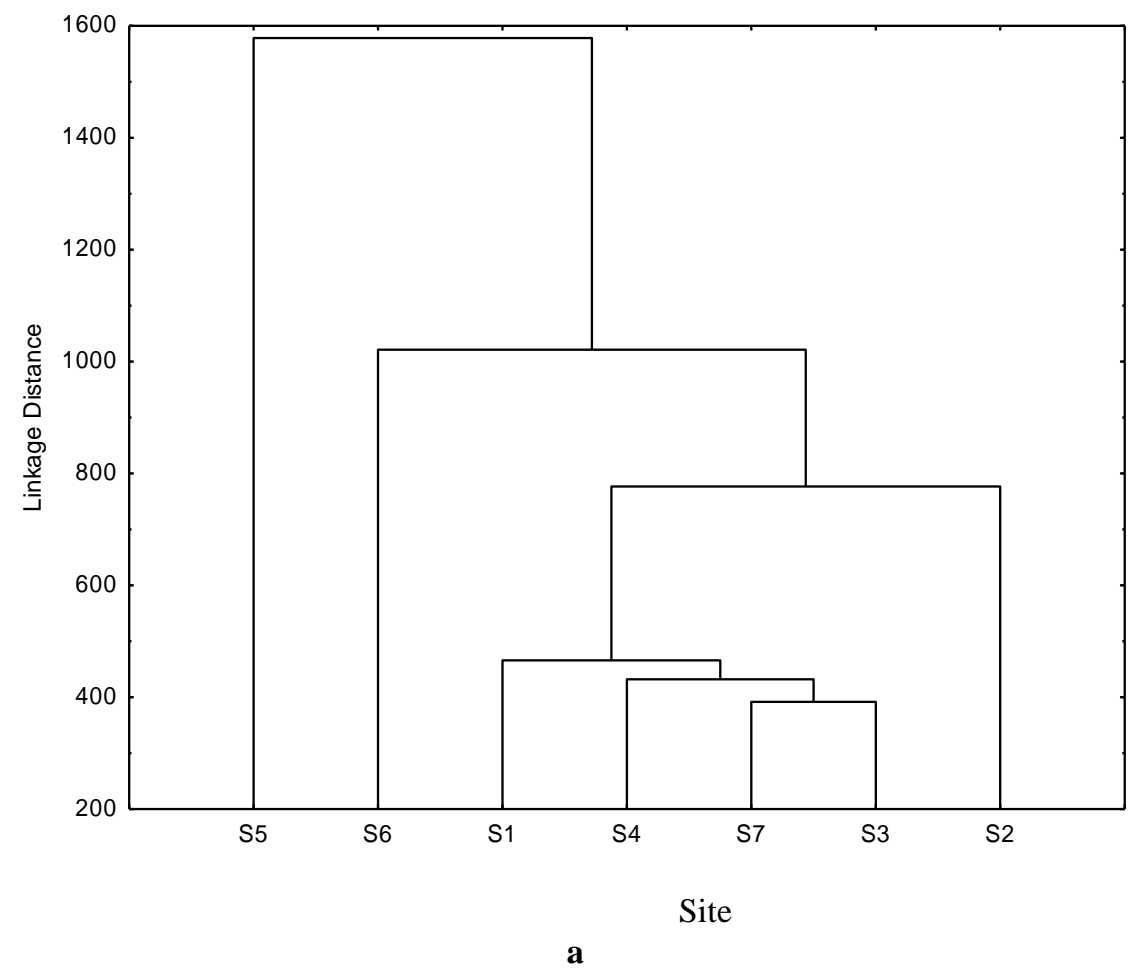




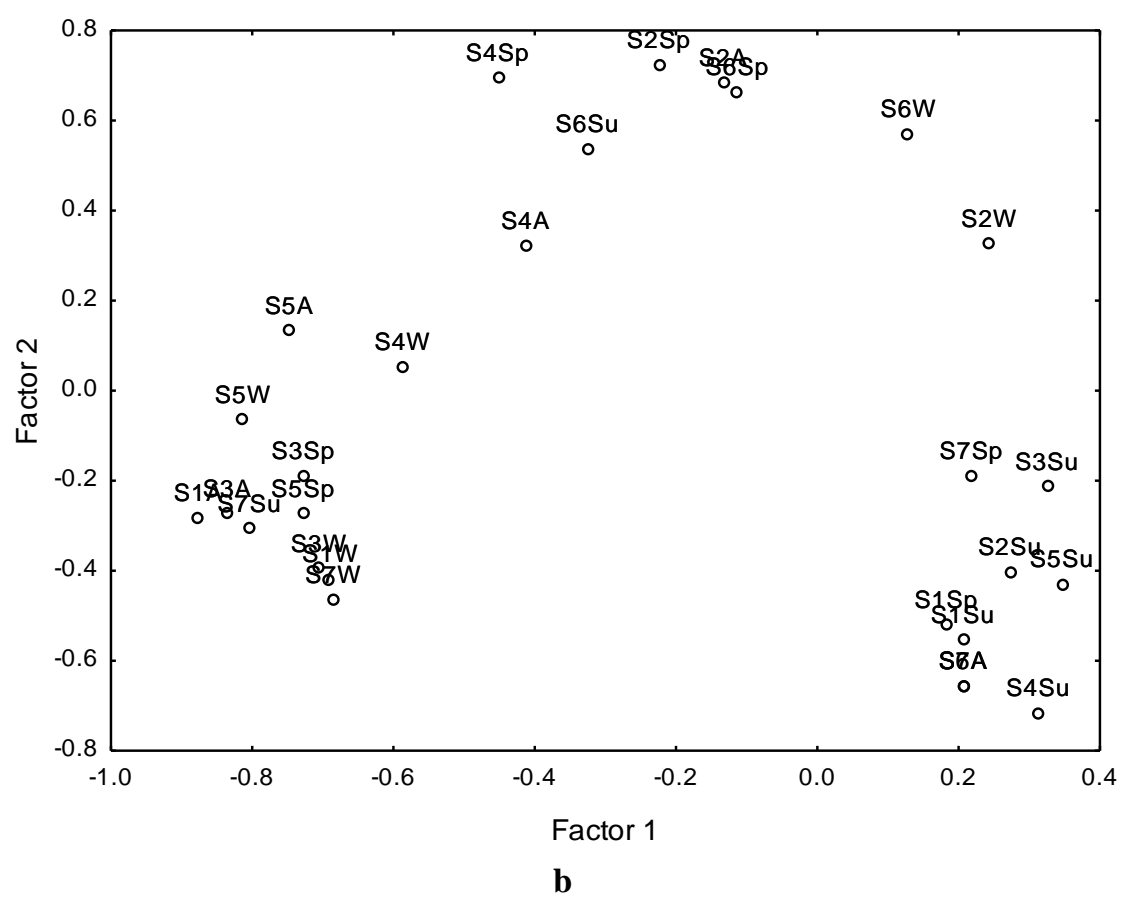

Figure 2. a Cluster analysis based on macroinvertebrates taxa collected at seven sampling sites along the Blyde River. $\boldsymbol{b}$ Seasonal macroinvertebrates distribution across the seven of the Blyde River $(W=$ winter, $S p=$ spring, $S u=$ summer and $A=$ autumn $)$

The number of tolerant families ranged from 10 at $\mathrm{S} 7$ to 13 at $\mathrm{S} 6$, while the number of moderately tolerant families ranged from 11 at S1 and S7 to 15 at S2 and S3, and the sensitive families ranged from two at S7 to five at S6 (Fig. 3). There were more numbers of tolerant, moderate tolerant and sensitive families collected in winter and spring (low flow seasons) than in summer and autumn (high flow seasons). The highest numbers of families were recorded in spring (32), followed by winter (27), autumn (25) and then summer (22). Thus, 12 more families were collected in the low-flow season than in the high-flow season. More than 7 tolerant families, 2 moderate tolerant families and 3 sensitive families were recorded at low-flow than high-flow seasons.

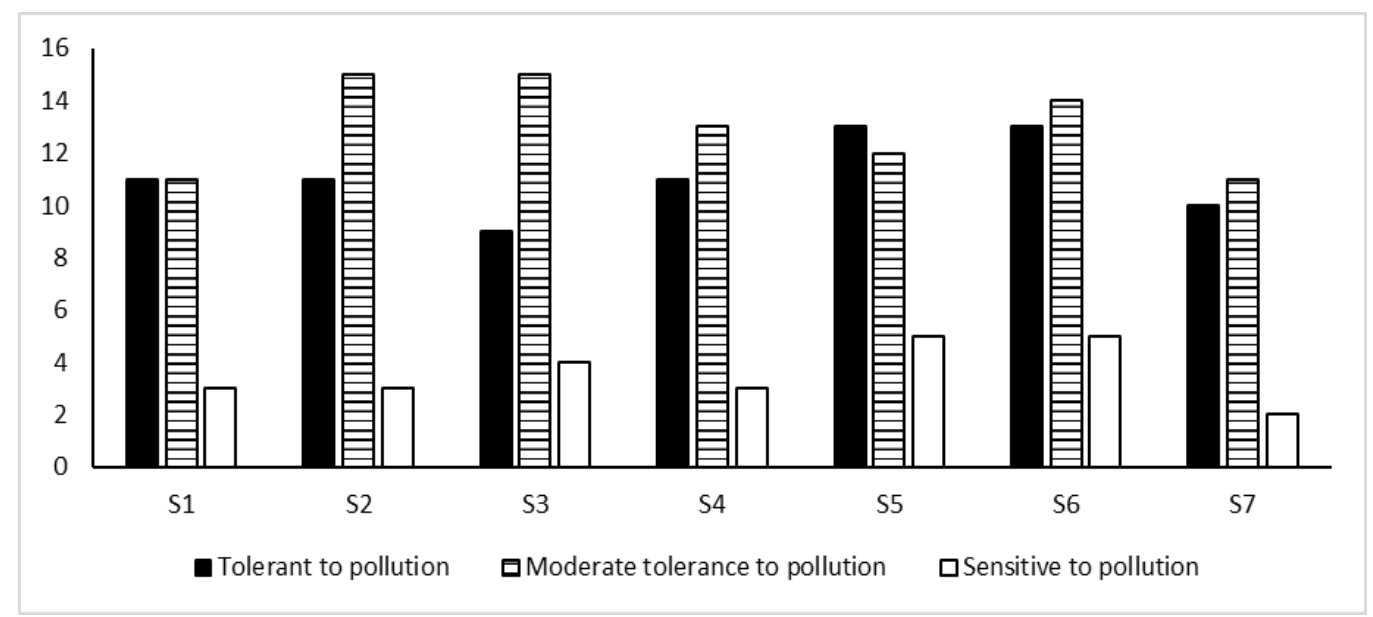

Figure 3. Tolerant, moderate tolerant and sensitive macroinvertebrate taxa recorded at the different sampling sites 
Table 2a. Taxonomic profile (order, family) and number of macroinvertebrate individuals recorded at different sites along the Blyde River

\begin{tabular}{|c|c|c|c|c|c|c|c|c|c|c|}
\hline Order & Family & Code & S1 & $\mathbf{S 2}$ & $\mathbf{S 3}$ & S4 & S5 & S6 & S7 & Total \\
\hline \multirow{6}{*}{ Ephemeroptera } & Baetidae & $\mathrm{BAE}$ & 227 & 594 & 138 & 417 & 501 & 330 & 276 & 2483 \\
\hline & Caenidae & CAE & 490 & 722 & 91 & 85 & 612 & 396 & 123 & 2519 \\
\hline & Heptageniidae & HEP & 7 & 123 & 95 & 272 & 103 & 267 & 40 & 907 \\
\hline & Teloganodidae & TEL & 139 & 98 & 23 & 30 & 139 & 151 & 95 & 675 \\
\hline & Leptophlebiidae & LEP & 1 & 3 & 20 & 3 & & 53 & 76 & 156 \\
\hline & Tricorythidae & TRI & 104 & 103 & 25 & 77 & 182 & 124 & 128 & 743 \\
\hline \multirow{3}{*}{ Trichoptera } & Hydropsychidae & HYD & 407 & 754 & 392 & 131 & 1108 & 631 & 260 & 3683 \\
\hline & Philopotamidae & PHI & & 11 & 17 & 15 & 226 & 2 & 2 & 273 \\
\hline & Leptoceridae & LEPC & & 3 & 3 & & & & & 6 \\
\hline \multirow{4}{*}{ Coleoptera } & Gyrinidae & GYR & 1 & 8 & 1 & 3 & 1 & 8 & 1 & 23 \\
\hline & Elmidae & ELM & 23 & 72 & 31 & 52 & 917 & 52 & 13 & 1160 \\
\hline & Helodidae & HEL & & & 2 & & 9 & 1 & & 12 \\
\hline & Psephenidae & PSE & 24 & 12 & 38 & 21 & 1 & 17 & & 113 \\
\hline Hemiptera & Naucoridae & NAU & & 1 & & & & & 1 & 2 \\
\hline \multirow{3}{*}{ Odonata } & Libellulidae & LIB & 10 & 12 & 6 & 5 & 50 & 4 & 10 & 97 \\
\hline & Aeshnidae & AES & 8 & 8 & & 2 & 1 & 1 & & 20 \\
\hline & Gomphidae & GOM & 68 & 21 & 3 & 2 & 2 & 1 & 15 & 112 \\
\hline \multirow{4}{*}{ Zygoptera } & Chlorocyphidae & CHL & 50 & 192 & 53 & 89 & 1 & 75 & 3 & 463 \\
\hline & Platycnemididae & PLA & & 3 & 2 & & & 1 & & 6 \\
\hline & Coenagrionidae & $\mathrm{COE}$ & 1 & & 1 & 4 & 5 & 3 & 3 & 17 \\
\hline & Protoneuridae & PRO & & & 1 & & & & & 1 \\
\hline \multirow{7}{*}{ Diptera } & Athericidae & ATH & 4 & 79 & 7 & 25 & 13 & 40 & 1 & 169 \\
\hline & Blephariceridae & BLE & & & & & 2 & 8 & & 10 \\
\hline & Tabanidae & TAB & 11 & 8 & 5 & 7 & 79 & 19 & 11 & 140 \\
\hline & Dixidae & DIX & & & 1 & 2 & 5 & 3 & & 11 \\
\hline & Chironomidae & $\mathrm{CHI}$ & 59 & 65 & 36 & 57 & 974 & 246 & 62 & 1499 \\
\hline & Muscidae & MUS & & 1 & & & 3 & 2 & & 6 \\
\hline & Simuliidae & SIM & 11 & 26 & 11 & 80 & 1223 & 855 & 12 & 2218 \\
\hline Plecoptera & Perlidae & PER & 1 & 5 & 2 & 3 & 9 & 6 & & 26 \\
\hline Crustacea & Potamonautidae & POT & 2 & 3 & & 8 & 11 & 8 & & 32 \\
\hline \multirow{2}{*}{ Annelida } & Hirudinea & HIR & & & & & 36 & 57 & & 93 \\
\hline & Oligochaeta & OLI & 18 & 7 & 3 & 2 & 4 & 32 & 42 & 108 \\
\hline \multirow[t]{4}{*}{ Mollusca } & Physidae & PHY & & & & & 1 & & 2 & 3 \\
\hline & Planorbidae & PLA & 1 & 3 & & 2 & & 17 & & 23 \\
\hline & Thiaridae & THI & 38 & 45 & 41 & 3 & 23 & 152 & 642 & 944 \\
\hline & Corbiculidae & $\mathrm{COR}$ & 3 & 14 & 5 & 43 & 635 & 239 & 140 & 1079 \\
\hline \multicolumn{3}{|c|}{ Total number of individuals } & 1708 & 2996 & 1053 & 1440 & 6876 & 3801 & 1958 & 19832 \\
\hline
\end{tabular}


Table $2 \boldsymbol{b}$. Abundance of macroinvertebrate families recorded over the four seasons in the Blyde River

\begin{tabular}{|c|c|c|c|c|c|c|}
\hline Order & Family & & Autumn & Winter & Spring & Summer \\
\hline \multirow{6}{*}{ Ephemeroptera } & Baetidae & BAE & 727 & 1386 & 191 & 179 \\
\hline & Caenidae & CAE & 181 & 1708 & 587 & 43 \\
\hline & Heptageniidae & HEP & 299 & 432 & 72 & 104 \\
\hline & Teloganodidae & TEL & 0 & 669 & 6 & 0 \\
\hline & Leptophlebiidae & LEP & 0 & 0 & 35 & 121 \\
\hline & Tricorythidae & TRI & 584 & 0 & 5 & 154 \\
\hline \multirow{3}{*}{ Trichoptera } & Hydropsychidae & HYD & 862 & 1740 & 666 & 415 \\
\hline & Philopotamidae & PHI & 273 & 0 & 0 & 0 \\
\hline & Leptoceridae & LEPC & 3 & 0 & 3 & 0 \\
\hline \multirow{4}{*}{ Coleoptera } & Gyrinidae & GYR & 0 & 11 & 11 & 1 \\
\hline & Elmidae & ELM & 511 & 340 & 293 & 16 \\
\hline & Helodidae & HEL & 2 & 0 & 10 & 0 \\
\hline & Psephenidae & PSE & 43 & 6 & 41 & 23 \\
\hline Hemiptera & Naucoridae & NAU & 0 & 0 & 1 & 1 \\
\hline \multirow{3}{*}{ Odonata } & Libellulidae & LIB & 35 & 40 & 7 & 15 \\
\hline & Aeshnidae & AES & 12 & 0 & 8 & 0 \\
\hline & Gomphidae & GOM & 32 & 42 & 31 & 7 \\
\hline \multirow{4}{*}{ Zygoptera } & Chlorocyphidae & $\mathrm{CHL}$ & 67 & 166 & 222 & 8 \\
\hline & Platycnemididae & PLA & 0 & 6 & 0 & 0 \\
\hline & Coenagrionidae & $\mathrm{COE}$ & 1 & 1 & 6 & 9 \\
\hline & Protoneuridae & PRO & 0 & 1 & 0 & 0 \\
\hline \multirow{7}{*}{ Diptera } & Athericidae & ATH & 16 & 53 & 95 & 5 \\
\hline & Blephariceridae & BLE & 1 & 3 & 5 & 1 \\
\hline & Tabanidae & $\mathrm{TAB}$ & 64 & 56 & 17 & 3 \\
\hline & Dixidae & DIX & 0 & 9 & 2 & 0 \\
\hline & Chironomidae & $\mathrm{CHI}$ & 299 & 1084 & 59 & 57 \\
\hline & Muscidae & MUS & 0 & 4 & 2 & 0 \\
\hline & Simuliidae & SIM & 82 & 1819 & 18 & 299 \\
\hline Plecoptera & Perlidae & PER & 13 & 6 & 7 & 0 \\
\hline Crustacea & Potamonautidae & POT & 16 & 5 & 4 & 7 \\
\hline \multirow{2}{*}{ Annelida } & Hirudinea & HIR & 0 & 90 & 3 & 0 \\
\hline & Oligochaeta & OLI & 46 & 22 & 17 & 23 \\
\hline \multirow{4}{*}{ Mollusca } & Physidae & PHY & 0 & 0 & 2 & 1 \\
\hline & Planorbidae & PLA & 0 & 5 & 18 & 0 \\
\hline & Thiaridae & THI & 18 & 111 & 585 & 230 \\
\hline & Corbiculidae & $\mathrm{COR}$ & 407 & 365 & 211 & 96 \\
\hline \multicolumn{3}{|c|}{ Total number of individuals } & 4594 & 10180 & 3240 & 1818 \\
\hline
\end{tabular}


Table 3. Spearman correlation of macroinvertebrate taxa at the sampling sites

\begin{tabular}{c|c|c|c|c|c|c|c}
\hline Site & S1 & S2 & S3 & S4 & S5 & S6 & S7 \\
\hline S1 & 1.000 & & & & & & \\
S2 & 0.813 & 1.000 & & & & & \\
S3 & 0.639 & 0.768 & 1.000 & & & & \\
S4 & 0.603 & 0.804 & 0.812 & 1.000 & & & \\
S5 & 0.405 & 0.519 & 0.431 & 0.624 & 1.000 & & \\
S6 & 0.608 & 0.674 & 0.640 & 0.781 & 0.576 & 1.000 & \\
S7 & 0.705 & 0.593 & 0.544 & 0.554 & 0.515 & 0.697 & 1.000 \\
\hline
\end{tabular}

The Canonical correspondence analysis (CCA) showed a correlation between some of the taxa and environmental variables (Fig. 4). The families Aeshnidae, Caenidae, Chlorocyphidae, Leptoceridae, Platycnemididae, Protoneuridae and Psephenidae were associated with high $\mathrm{pH}$ and dissolved oxygen. The TDS, temperature, salinity and electrical conductivity, affected the families Coenagrionidae, Corbiculidae, Chironomidae, Physidae and Tricorythidae. The taxa-environment correlations for first and second axes were 0.99 , and the cumulative percentage variance of taxa-environment relation for first and second axes combination was $65.5 \%$ (Table 4).

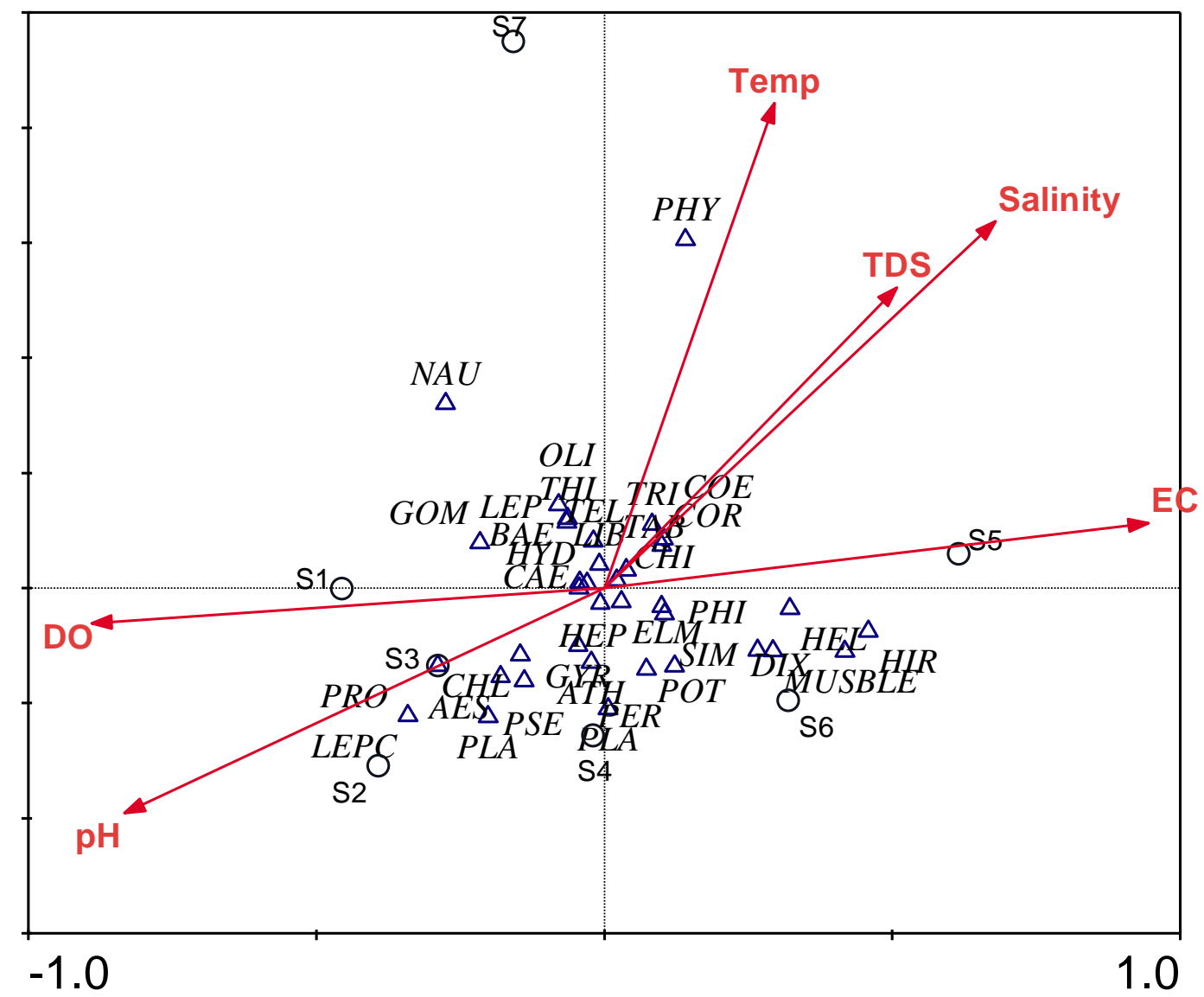

Figure 4. Canonical correspondence analysis (CCA) ordination of the macroinvertebrates collected at the sampling sites (arrows indicate environmental variables; circles denote sites; triangles denote family code names) 
Table 4. Eigenvalues of the correlation matrix of the taxa-environment relation

\begin{tabular}{c|c|c|c|c|c}
\hline Macroinvertebrates and water parameters & Axis 1 & Axis 2 & Axis 3 & Axis 4 & Total inertia \\
\hline Eigenvalues & 0.084 & 0.056 & 0.033 & 0.025 & 0.250 \\
Taxa-environment correlations & 0.994 & 0.990 & 0.993 & 0.923 & \\
Cumulative percentage variance of & & & & & \\
- taxa data & 33.5 & 56.1 & 69.5 & 79.6 & \\
- taxa-environment relation & 39.1 & 65.5 & 81.1 & 92.9 & \multirow{2}{*}{ Sum of all eigenvalues } \\
$\quad$ & & & & & 0.250 \\
Sum of all canonical eigenvalues & & & & & 0.214 \\
$\quad$ F-ratio & 3.99 & & & & \\
$p$-value of CCA axis 1 & 0.002 & & & & \\
\hline
\end{tabular}

\section{Discussion}

\section{Physicochemical parameters}

The physicochemical parameters showed relatively little changes across sites and seasons. There was a strong positive correlation between $\mathrm{pH}$ and $\mathrm{DO}$, and could be due to the fact that both $\mathrm{pH}$ and $\mathrm{DO}$ are affected by algal photosynthesis, respiration, temperature and oxidative decomposition of organic matter (Zang et al., 2011). Rivers in less disturbed areas are frequently characterised by low conductivity, turbidity and silt load, hence good water quality. In the Blyde River, the sites generally had moderate temperatures, TDS and conductivity values. However, TDS, salinity and sulphate were relatively high at $\mathrm{S} 7$ (the confluence of the Blyde and Olifants rivers), and could be due to increased runoff from human activities along the river to downstream or from the Olifants River. The DO levels were high throughout the sampling periods and the sites, with the highest level recorded in winter, as dissolved oxygen is temperature dependent. Nutrients levels were not too high despite the intensive agricultural activities in the catchment (DWAF, 1996; de Villiers and Thiart, 2007).

\section{Macroinvertebrates}

The macroinvertebrate assemblages in the Blyde River were rich in Ephemeroptera, Diptera and Trichoptera (Table 2a), and this trend is in support of other studies in both temperate and tropical rivers and streams (Al-Shami et al., 2013a, b; Jun et al., 2016). Taxa diversity is said to be variable in rivers in response to disturbance, suitable habitat availability and resource availability. Higher diversity is an indication of equal or close to equal opportunity of co-existence (Olomukoro and Ezemonye, 2007). A decreased diversity with corresponding increased abundance of few taxa is an indication of community disturbance and imbalance (Morphin-Kani and Murugesan, 2014). The low number of sensitive families at S7 and high numbers of tolerant species, could be due to poor water quality from the Olifants River. Furthermore, the low number of taxa at S3 could be due to the high-water current throughout the sampling period, resulting in less favourable conditions for many macroinvertebrates to survive in such an environment.

The high number of individuals and families of Ephemeroptera could be due to high oxygen concentration and fast flowing waters (Jun et al., 2016; Rasifudi et al., 2018). The presence of these taxa at all the sites indicates a high level of water quality at most parts of the river (Griffin et al., 2015). In addition, the high number of individuals from 
the family Hydropsychidae (Tricoptera), at all the sites could further confirm the good quality of the water. The presence of sensitive taxa is an indication of good habitat structure and good water quality (Lopez-Doval et al., 2010; Matlou et al., 2017). The cluster analysis shows only three main groupings, an indication that the conditions of most of the sites are similar. This is confirmed by the Spearman correlation which shows positive relationship among all the sampling sites, with high correlation among the third cluster group ( $1,52, \mathrm{~S} 3, \mathrm{~S} 4$ and S7). The seasonal macroinvertebrate distribution among the sites rarely showed any variation (Fig. 2b). While seasonality can be a driven force of river community dynamics, its effect is regulated by the likelihood of its recurrence (Tonkin et al., 2017). The lack of seasonality effect is an indication of the relative lack of a significant variability in environmental conditions of the river. The high number of macroinvertebrates recorded at S5 from different tolerant groups such as, Hydropsychidae, Simuliidae, Chironomidae and Elmidae could be attributed to good biotope diversity (higher habitat heterogeneity), as this site was characterised by bedrock, sand, areas of high current, pools and sparse vegetation. Furthermore, the high abundance of Simuliidae at S5 could be due to the presence of the Weir above the sampling site. High presence of Simuliidae has been reported below many impoundments, and their abundance is linked to reservoir outflows (Boon, 1998; Marchetti et al., 2014; Rasifudi et al., 2018).

There was seasonal variation in the composition of macroinvertebrates in the Blyde River. The high number of taxa and abundance during winter could be due to relatively good water quality as a result of less discharge from the catchment. During raining season, which usually starts in spring through to autumn in the area of the study, the river receives a lot of discharge from the catchment which may destroy the microhabitat of the macroinvertebrates. Furthermore, high flows which normally occur in raining season are known to affect aquatic macroinvertebrates both directly and indirectly through changes to habitat. Substrates of macroinvertebrats can be moved down-stream (Piniewki et al., 2017).

Most taxa sampled clumped at the centre of the CCA ordination plot, suggesting that no particular measured environmental variable defined the taxa distribution (Niba and Sakwe, 2018). It also confirms the fact that the conditions at most of the sites are similar and therefore may support similar macroinvertebrate communities. The taxaenvironmental correlation for both axes 1 and 2 was 0.99 , which indicates high predictive power of the selected environmental variables. Many of the pollution intolerant taxa could live in areas with high $\mathrm{DO}$ and $\mathrm{pH}$ and many of the pollution tolerant taxa could group in areas with high EC, TDS, salinity and temperature. Thus, interactions of macroinvertebrate communities may be influenced by abiotic factors in the environment (Florencio et al., 2013; Heino, 2013).

\section{Conclusion}

Despite the active agricultural activities in the Blyde River catchment, the aquatic community was indicative of good water quality. The high diversity and the presence of high abundance of sensitive taxa confirm the good quality or/and habitat heterogeneity of most parts of the river. However, the water from the Olifants River might have affected the quality of the water at S7 (the confluence of the Blyde and the Olifants River), hence the distribution of the macroinvertebrate communities was characterised by high number of pollutant taxa, Mollusca, especially Thiaridae. Seasonal variation of 
the distribution of macroinvertebrates was also observed. The results suggest that currently the human activities along the Blyde River has little impact on the integrity of the river system. Though the current activities may not pose a threat to the water quality and benthic macroinvertebrates in the river, further monitoring is necessary due to increasing human activities in the catchment of the river. The study revealed that combination of physicochemical and biological measures in water quality assessment provides positive and promising results as they show sensitivity to environmental changes hence, aquatic macroinvertebrates are good biological indicators of pollution.

Acknowledgements. We are grateful to the Flemish Interuniversity Council (VLIR-UOS), Belgium for providing financial support for the study.

\section{REFERENCES}

[1] Addo-Bediako, A., Matlou, K., Makushu, E. (2018): Heavy metal concentrations in water and sediment of the Steelpoort River, Olifants River System, South Africa. - African Journal of Aquatic Science 43(4): 413-416. DOI: 10.2989/16085914.2018.1524745.

[2] Al-Shami, S. A., Heino, J., Che Salmah, M. R., Abu Hassan, A., Suhaila, A. H., Madziatul, R. M. (2013a): Drivers of beta diversity of macroinvertebrate communities in tropical forest streams. - Freshwater Biology 58: 1126-1137.

[3] Al-Shami, S. A., Che Salmah, R., Abu Hassan, A., Madziatul, R. M. (2013b): Biodiversity of stream insects in the Malaysian Peninsula: spatial patterns and environmental constraints. - Ecological Entomology 38: 238-249.

[4] Ashton, P. J., Love, D., Mahachi, H., Dirks, P. H. G. M. (2001): An overview of the impact of mining and mineral processing operations on water resources and water quality in the Zambezi, Limpopo and Olifants Catchments in Southern Africa. - Contract Report to the Mining, Minerals and Sustainable Development (Southern Africa) Project, by CSIR-Environmentek, Pretoria, South Africa and Geology Department, University of Zimbabwe-Harare. Report No. ENV-P-C 2001-042.xvi.

[5] Boon, P. I. (1988): The impact of river regulation on invertebrate communities in the U. K. regulated rivers. - Research and Management 2: 389-409.

[6] British Columbia-Ministry of Environment and Climate Change Strategy (BCMECCS) (2019): British Columbia Approved Water Quality guidelines: Aquatic life, Wildlife and Agriculture. https://www2gov.bc.ca/gov/content/environment/airland-water/water/water-quality/water-quality-reference-documents. Accessed on 20/20/2020.

[7] Canadian Council of Ministers of the Environment (CCME) (2012): Environmental Quality Guidelines: Water Quality Guidelines for the Protection of Aquatic Life and Sediment Quality Guidelines for the Protection of Aquatic Life. - Canadian Council of Ministers of the Environment, Winnipeg. http://ceqg-rcqe.ccme.ca/ (accessed 05-052012).

[8] Dalu, T., Froneman, P. W. (2016): Diatom based water quality monitoring in Africa: challenges and future prospects. - Water SA 42: 551-559.

[9] De Villiers, S., Thiart, C. (2007): The nutrient status of South African rivers: concentrations, trends and fluxes from the 1970s to 2005. - South African Journal of Science 103: 343-349.

[10] Department of Water Affairs and Forestry (DWAF) (1996): South African Water Quality Guidelines. Volume 7: Aquatic Ecosystems. Second Ed. - DWAF, Pretoria, South Africa.

[11] Dickens, C. W., Graham, P. (2002): The South African Scoring System (SASS) version 5 rapid bio-assessment method for rivers. - African Journal of Aquatic Science 27: 1-10. 
[12] Ferreira, A. R. L., Sanches Fernandes, L. F., Cortes, R. M. V., Pacheco, F. A. L. (2017): Assessing anthropogenic impacts on riverine ecosystems using nested partial least squares regression. - Science of the Total Environment 583: 466-477.

[13] Florencio, M., Gómez-Rodríguez, C., Serrano, L., Díaz-Paniagua, C. (2013): Competitive exclusion and habitat segregation in seasonal macroinvertebrate assemblages in temporary ponds. - Freshwater Science 32: 650-662.

[14] Gerber, A., Gabriel, M. J. M. (2002): Aquatic Invertebrates of South African Rivers: Field Guide. - Department of Water Affairs and Forestry, Pretoria, South Africa.

[15] Grab, S. (2014): Spatio-temporal attributes of water temperature and macroinvertebrate assemblages in the headwaters of the Bushmans River, southern Drakensberg. - Water SA 40: 19-26.

[16] Griffin, D., Myers, S., Sloan, S. (2015): Implications on distribution and abundance of benthic macroinvertebrates in the Maple River based on water quality and habitat type. General Ecology 381: 1-17.

[17] Grobler, D. F. (1994): A note on the occurrence of metals in the Olifants River, Eastern Transvaal, South Africa. - Water SA 20: 195-205.

[18] Grönroos, M., Heino, J. (2012): Species richness at the guild level: effects of species pool and local environmental conditions on stream macroinvertebrate communities. - Journal of Animal Ecology 81: 679-691.

[19] Heino, J. (2009): Biodiversity of aquatic insects: spatial gradients and environmental correlates assemblage-level measures at large scales. - Freshwater Review 2: 1-29.

[20] Hunt, L., Bonetto, C., Marrochi, N., Scalise, A., Fanelli, S., Liess, M., Lydy, M. J., Chiu, M. C., Resh, V. H. (2017): Species at Risk (SPEAR) index indicates effects of insecticides on stream invertebrate communities in soy production regions of the Argentine Pampas. - Science of the Total Environment 580: 699-709.

[21] Jun, Y-C., Kim, N-Y., Kim, S-H., Park, S-H., Kong, D-S., Hwang, S-J. (2016): Spatial distribution of benthic macroinvertebrate assemblages in relation to environmental variables in Korean nationwide streams. - Water 8: 1-20.

[22] Külköylüoğlu, O. (2004): On the usage of ostracods (Crustacea) as bioindicator species in different aquatic habitats in the Bolu region, Turkey. - Ecological Indicators 4: 139-147.

[23] Li, L., Zheng, B., Liu, L. (2010): Biomonitoring and bioindicators used for river ecosystems: definitions, approaches and trends. - Procedia Environmental Sciences 2: 1510-1524.

[24] Lopez-Doval, J. C., Großschartner, M., Höss, S., Orendt, C., Traunspurger, W., Wolfram, G., Munoz, I. (2010): Invertebrate communities in soft sediments along a pollution gradient in a Mediterranean river (Llobregat, NE Spain). - Limnetica 29: 311-322.

[25] Machethe, C. L., Mollel, N., Ayisi, K., Mashatola, M., Anim, F., Vanasche, F. (2004): Smallholder Irrigation and Agricultural Development in the Olifants River Basin of Limpopo Province: Management Transfer, Productivity, Profitability and Food Security Issues. - Water Research Commission, Pretoria.

[26] Marchetti, M. P., Esteban, E., Smith, A. N. H., Pickard, D., Richards, A. B., Slusark, J. (2014): Measuring the ecological impact of long term flow disturbance on the macroinvertebrate community in a large Mediterranean climate river. - Journal of Freshwater Ecology 26: 459-480.

[27] Masese, F. O., Kitaka, N., Kipkembo, J., Gettel, G. M., Irvine, K., Mcclain, M. E. (2014): Macroinvertebrate functional feeding groups in Kenyan highland streams: evidence for a diverse shredder guild. - Freshwater Science 33(2): 435-450.

[28] Matlou, K., Addo-Bediako, A., Jooste, A. (2017): Benthic macroinvertebrate assemblage along a pollution gradient in the Steelpoort River, Olifants River System. - African Entomology 25: 445-453.

[29] Morphin-Kani, K., Murugesan, A. G. (2014): Assessment of River Water Quality Using Macroinvertebrate Organisms as Pollution Indicators of Tamirabarani River Basin, Tamil Nadu, India. - International journal of Environmental Protection 4: 1-14. 
[30] Niba, A., Sakwe, S. (2018): Turnover of benthic macroinvertebrates along the Mthatha River, Eastern Cape, South Africa. Implications for water quality biomonitoring using indicator species. - Journal of Freshwater Ecology 33: 157-171.

[31] Oberholster, P. J., Botha, A., Chamier, J., De Klerk, A. R. (2013): Longitudinal trends in water chemistry and phytoplankton assemblage downstream of the rivers WWTP in the upper Olifants River. - Eco hydrology and Hydrobiology 13: 41-51.

[32] Olomukoro, J. O., Ezemonye, L. I. N. (2007): Assessment of the macro-invertebrate fauna of rivers in Southern Nigeria. - African Zoology 42(1): 1-11.

[33] Piniewski, M., Prudhomme, C., Acreman, M. C., Tylec, L., Oglecki, P., Okruszko, T. (2017): Responses of fish and invertebrates to floods and droughts in Europe. Ecohydrology 10: 1-17. doi.org/10.1002/eco.1793.

[34] Rasifudi, L., Addo-Bediako, A., Bal, K., Swemmer, A. (2018): Distribution of benthic macroinvertebrates in the Selati River of the Olifants River System, South Africa. African Entomology 26(2): 398-406.

[35] Raven, B. W. (2004): Water Affairs in the Lower Blyde River: The Role of DWAF in Local Water Management. - IMWI Working Paper. IMWI, Wageningen.

[36] Rosenberg, D. M., Resh, V. H. (eds.) (1993): Freshwater Biomonitoring and Benthic Macroinvertebrates. - Chapman \& Hall, New York.

[37] Santos, R. M. B., Sanches Fernandes, L. F., Cortes, R. M. V., Varandas, S. G. P., Jesus, J. J. B., Pacheco, F. A. L. (2017): Integrative assessment of river damming impacts on aquatic fauna in a Portuguese reservoir. - Science of the Total Environment 601-602: 1108-1118.

[38] Ter Braak, C. J. F., Smilauer, P. (2012): Canoco Reference Manual and User's Guide: Software for Canonical Community Ordination (version 5). - Microcomputer Power, New York.

[39] Tonkin, J. D., Bogan, M. T., Bonada, N., Rios-Touma, B., Lytle, D. A. (2017): Seasonality and predictability shape temporal species diversity. - Ecology 98: 1201-1216.

[40] Wolmarans, C. T., Kemp, M., De Kock, K. N., Roets, W., Van Rensburg, L., Quinn, L. (2014): A semi-quantitative survey of macroinvertebrates at selected sites to evaluate the ecosystem health of the Olifants River. - Water SA 40(2): 245-254.

[41] Zang, C., Huang, S., Wu, M., Du, S., Scholz, M., Gao, F., Lin, C., Guo, Y., Dong, Y. (2011): Comparison of relationships between $\mathrm{pH}$, dissolved oxygen and chlorophyll a for aquaculture and non-aquaculture waters. - Water Air Soil Pollution 219: 157-174. 